\title{
Application of a combined risk-based, remedial and redevelopment methodology on a former cokes plant
}

\author{
P. Schrooten ${ }^{1}$, A. Coopman ${ }^{1} \&$ V. Kindt ${ }^{2}$ \\ ${ }^{1}$ SORESMA N.V., Environmental Consultants, Belgium \\ ${ }^{2}$ OVAM, Flemish Waste Agency, Belgium
}

\begin{abstract}
Many former cokes plants and gasworks sites are characterised by heavily contaminated (PAH, TPH, creosote, cyanide, BTEX, etc) soils and groundwater and are presently situated in economically interesting and valuable locations (near city centres, close to roads and waterways). To determine the potential for redevelopment of these brownfield sites, an evaluation tool was developed based on three main steps: Risk, Remediation and Redevelopment (RRR). This methodology was applied on the former Carcoke cokes plant located in the Zeebrugge harbour area, Belgium. In a first step the human health risks posed by the known contaminations were quantified for different protective scenarios for each individual area of a grid superposed on the site. These scenarios went from no protection measures to a removal and isolation of the contamination. In a second step six potential redevelopment scenarios were evaluated based on their minimum infrastructural needs and potential for human exposure. In a third step the protection measures were converted in concrete remedial actions taking into account feasibility and local legislation. For each remedial technique and each area a cost was determined. The combination of the three steps (RRR) lead to a matrix that was used to determine the optimal redevelopment scenario with a minimal remedial cost and sufficient guarantee to prevent exposure. The RRR-methodology reduced the remedial costs by over 30\% compared to the initial more traditional risk-based remedial plan. It also determined what areas were not suitable for build-on activities (warehouse, offices) taking into account "reasonable" remedial costs to sufficiently reduce the exposure risk. The methodology was also used to allow for temporary use of the site as an outdoor storage facility taking into account the necessary protection measures.

Keywords: risk-based, remediation, redevelopment, cokes plant, gasworks, cost reduction, land-use, soil contamination, human health, evaluation methodology.
\end{abstract}




\section{Introduction}

In 1996, after more than 100 years of coking activities, the Carcoke coking plant in Zeebrugge, Belgium was closed. The Carcoke company was bankrupt and the site became property of the Flemish community. A first step in the redevelopment was the remediation of the site. In 2003, after several years of soil and groundwater investigations [1-3], a risk-based remedial plan [4] was developed on behalf of the Flemish Waste Agency (OVAM). In 2004, the first phase of the remediation works was started, mainly the demolishing of buildings and installations. This was finished in September 2005.

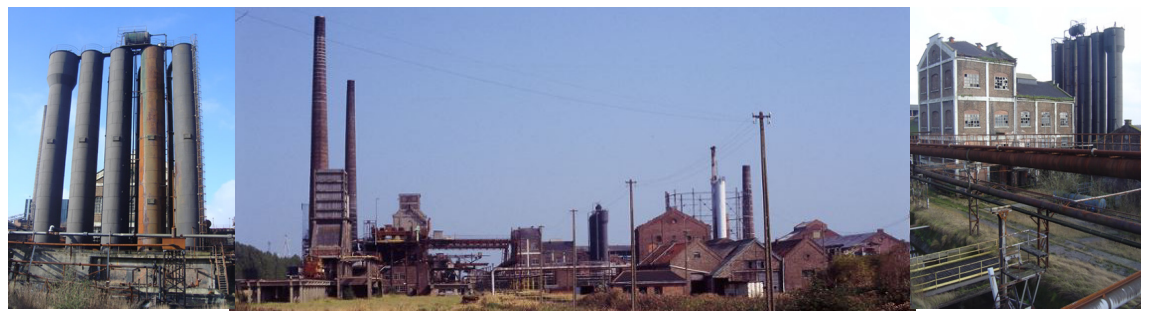

Figure 1: Carcoke before the remediation works (left: scrubbers, middle: general view, right: benzol factory).

In 2005, OVAM decided to revaluate the soil and groundwater remedial plan and to also take into account future planning and potential activities. Soresma was commissioned by the OVAM to undertake this task. The methodology and findings are presented in this paper.

\section{Methodology}

The methodology to evaluate and bring together the parameters that determine the final costs of the remediation and redevelopment of the contaminated site, are based on three main aspects: Risk (human health), Remediation (technique), Redevelopment (land use).

- $\quad$ Risk is the first factor that will drive the remedial need. If a risk, being a potential negative impact on humans, is present, remediation will be necessary. A risk can be quantified based on human health exposure models. The result is a risk index that indicates how large the impact of the soil and groundwater contamination is for a certain use of the site (housing, offices, agriculture, etc). The larger the risk, the higher the need to remediate. A risk can be reduced by remediation of the site or by minimising the amount of exposure. This can be done by taking protective measures.

- Remediation technique that will be used to clean up the soil and groundwater will be determined by all kinds of parameters: the 
properties of the contaminants, the properties of the soil and groundwater, the amount of contamination present, the feasibility of the technique, etc.

- Redevelopment, namely the new destination of the site, is not as much determined by the contamination but mainly by spatial planning, economical needs, site location and investors.

The influence of these three factors is schematically presented in Figure 2. This schema forms the basis of the RRR-methodology.

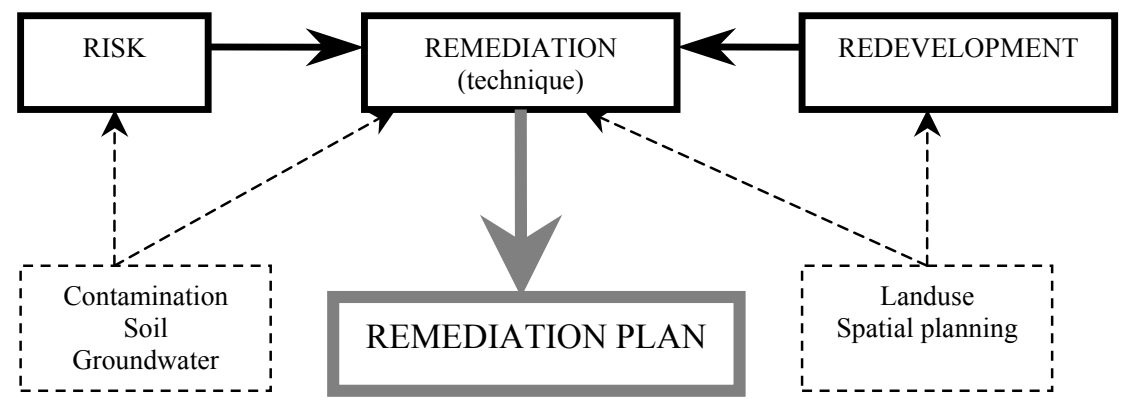

Figure 2: Schema RRR-methodology.

\subsection{Risk determination}

The first step of the methodology is to determine the risks associated with the soil and groundwater contamination. Two human health exposure models are used to quantify the risks: the Flemish "Vlier-Humaan" [5] model and the US EPA " $R B C A$ " $[6,7]$ model. The " $R B C A$ " model is used in addition to the "VlierHumaan" model for the exposure pathways that cannot be calculated with the Flemish model. The risks are determined for the most toxic or most abundant compounds present at the site, namely: PAH, cyanide, BTEX, heavy metals and $\mathrm{TPH}$.

To make it possible to evaluate and compare different areas of the Carcoke site (comprising a total area of approx. 16,5 ha), the site is divided into 66 areas of equal size. For each area, where soil and groundwater analyses are available, a quantitative risk assessment is performed. The results (risk indices) for all the different compounds for each area are normalised. This allows comparison between different areas. For areas where no measurements are available an extrapolation based on the results of adjacent areas and former activities [8] is made. Figure 3 presents the areas where soil measurements are available and where risks are identified by the models.

The risks are calculated for an industrial use with or without buildings and with different protection measure scenarios: a horizontal isolation, contaminant source removal, soil vapour extraction and combinations of these. Each protection measure alters the total surface area where a risk is identified. The 
effectiveness of the protection measures is determined by the reduction of the total risk defined area. Table 1 presents the risk reduction by the different protection measures.
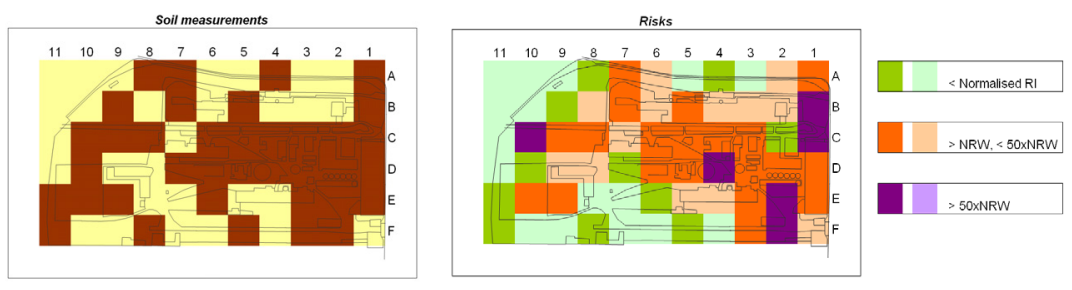

Figure 3: Left: in dark coloured areas soil measurements are available. Right: different colours indicate different risks.

Table 1: $\quad$ Risk reduction for different scenarios and protection measures for soil and groundwater contaminations.

Soil contamination
\begin{tabular}{|c|l|l|c|c|}
\hline & $\begin{array}{l}\text { Industrial } \\
\text { use with }\end{array}$ & $\begin{array}{c}\text { Protection } \\
\text { measures }\end{array}$ & $\begin{array}{c}\text { Total } \\
\text { surface } \\
\text { area } \\
\text { posing } \boldsymbol{a} \\
\text { risk }\end{array}$ & $\begin{array}{c}\text { Risk } \\
\text { reduction }\end{array}$ \\
\hline 1 & $\begin{array}{l}\text { No } \\
\text { buildings }\end{array}$ & None & $59 \%$ & -- \\
\hline 2 & $\begin{array}{l}\text { No } \\
\text { buildings }\end{array}$ & Soil cover & $9 \%$ & $85 \%$ \\
\hline 4 & $\begin{array}{l}\text { No } \\
\text { buildings }\end{array}$ & $\begin{array}{l}\text { Contaminant } \\
\text { source zone } \\
\text { removal }\end{array}$ & $52 \%$ & $13 \%$ \\
\hline 5 & $\begin{array}{l}\text { No } \\
\text { buildings }\end{array}$ & $\begin{array}{l}\text { Contaminant } \\
\text { source zone } \\
\text { removal and } \\
\text { soil cover }\end{array}$ & $0 \%$ & $100 \%$ \\
\hline 6 & $\begin{array}{l}\text { With } \\
\text { buildings } \\
\text { sontaminant } \\
\text { removal and } \\
\text { soil cover }\end{array}$ & $58 \%$ & $3 \%$ \\
\hline 7 & $\begin{array}{l}\text { Soil vapour } \\
\text { extraction, } \\
\text { contaminant } \\
\text { source zone } \\
\text { removal and } \\
\text { soil cover }\end{array}$ & $0 \%$ & $100 \%$ \\
\hline buildings & & \\
\hline
\end{tabular}

Groundwater contamination
\begin{tabular}{|c|l|l|c|c|}
\hline \multicolumn{1}{|c|}{} & $\begin{array}{l}\text { Industrial } \\
\text { use with }\end{array}$ & $\begin{array}{c}\text { Protection } \\
\text { measures }\end{array}$ & $\begin{array}{c}\text { Total } \\
\text { surface } \\
\text { area } \\
\text { posing } \boldsymbol{a} \\
\text { risk }\end{array}$ & $\begin{array}{c}\text { Risk } \\
\text { reduction }\end{array}$ \\
\hline 1 & $\begin{array}{l}\text { No } \\
\text { buildings }\end{array}$ & None & $21 \%$ & -- \\
\hline 2 & $\begin{array}{l}\text { No } \\
\text { buildings }\end{array}$ & Soil cover & $21 \%$ & -- \\
\hline 4 & $\begin{array}{l}\text { No } \\
\text { buildings }\end{array}$ & $\begin{array}{l}\text { Contaminant } \\
\text { source zone } \\
\text { removal }\end{array}$ & $0 \%$ & $100 \%$ \\
\hline 5 & $\begin{array}{l}\text { No } \\
\text { buildings }\end{array}$ & $\begin{array}{l}\text { Contaminant } \\
\text { source zone } \\
\text { removal and } \\
\text { soil cover }\end{array}$ & $0 \%$ & $100 \%$ \\
\hline 6 & $\begin{array}{l}\text { With } \\
\text { buildings } \\
\text { sontaminant } \\
\text { removal and } \\
\text { soil cover }\end{array}$ & $67 \%$ & $214 \%$ \\
\hline 7 & $\begin{array}{l}\text { Soil vapour } \\
\text { extraction, } \\
\text { contaminant } \\
\text { source zone } \\
\text { removal and } \\
\text { soil cover }\end{array}$ & $0 \%$ & $100 \%$ \\
buildings & & \\
\hline
\end{tabular}

This evaluation shows that if buildings are to be constructed on the contaminated area and source zone removal and a protective cover are the only protection measures in place, the risk from the groundwater contamination will not be reduced but instead will increase. This is due to vapour intrusion into the buildings from the groundwater contamination. So a protection measure (soil vapour extraction) is essential to prevent exposure, when the contaminated groundwater area is build upon. The scenario where no buildings are present and a soil cover (e.g. concrete or asphalt cover) is used, the surface area posing a risk 
is reduced by $85 \%$ for exposure to the soil contamination. This indicates that a limited protective measure allows for a significant increase in available surface area for outdoor industrial activities.

\subsection{Redevelopment determination}

The next step is to relate the different scenarios with actual relevant redevelopment options for industrial use. Therefore a regional analyses of the economic needs and potential land uses is performed. Based on spatial planning, the location of the site, the accessibility, the main activities in and around the harbour area and future development of the Zeebrugge harbour 6 potential industrial activities are selected for further evaluation. These are presented in Figure 4.
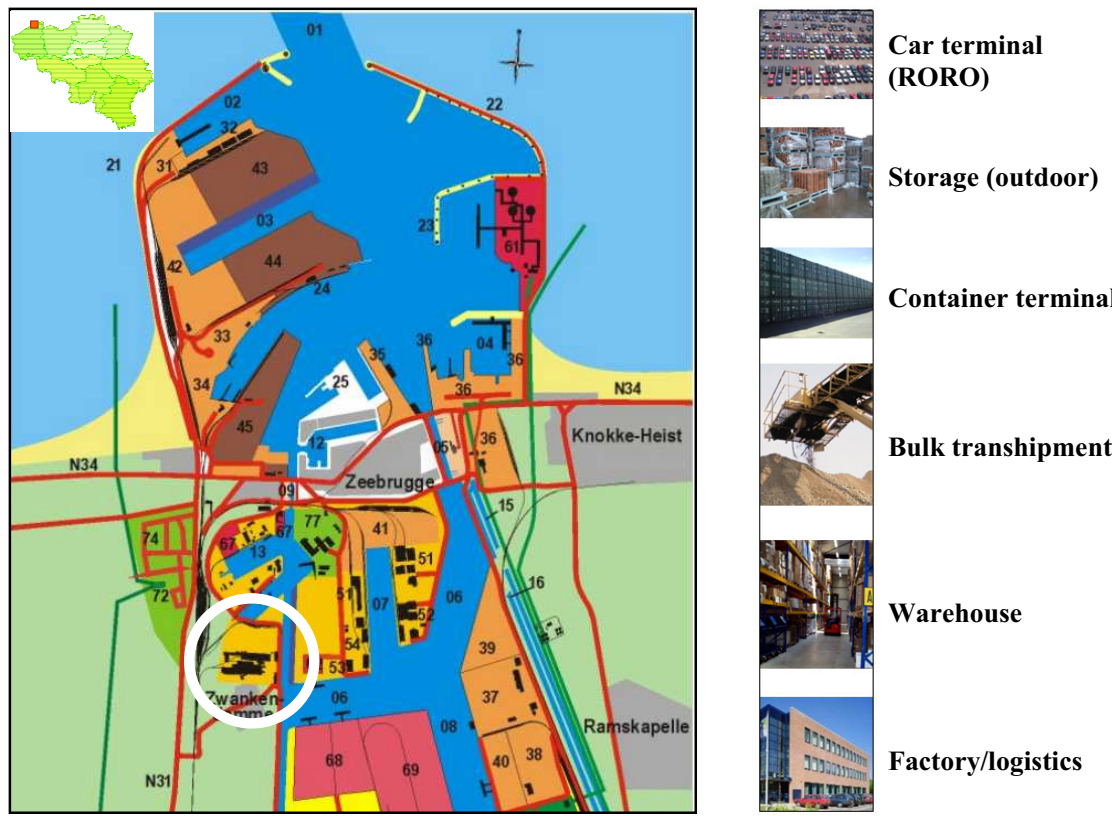

Figure 4: $\quad$ Site location map and 6 selected industrial activities.

Based on the different scenarios for the different protection measures and on the 6 selected industrial activities an evaluation is performed to determine which activities can be combined with which protection measure. This evaluation shows that 2 groups of activities can be distinguished: outdoor (car terminal, storage, container terminal and bulk transhipment) and indoor activities (warehouse and factory/logistics). The potential for the implementation of the outdoor activities is determined by the presence of a surface cover and source zone removal. Additionally the indoor activities require the implementation of a soil vapour extraction system to prevent indoor exposure. Figure 5 presents for the different protection measures, the areas where activities can take place. 


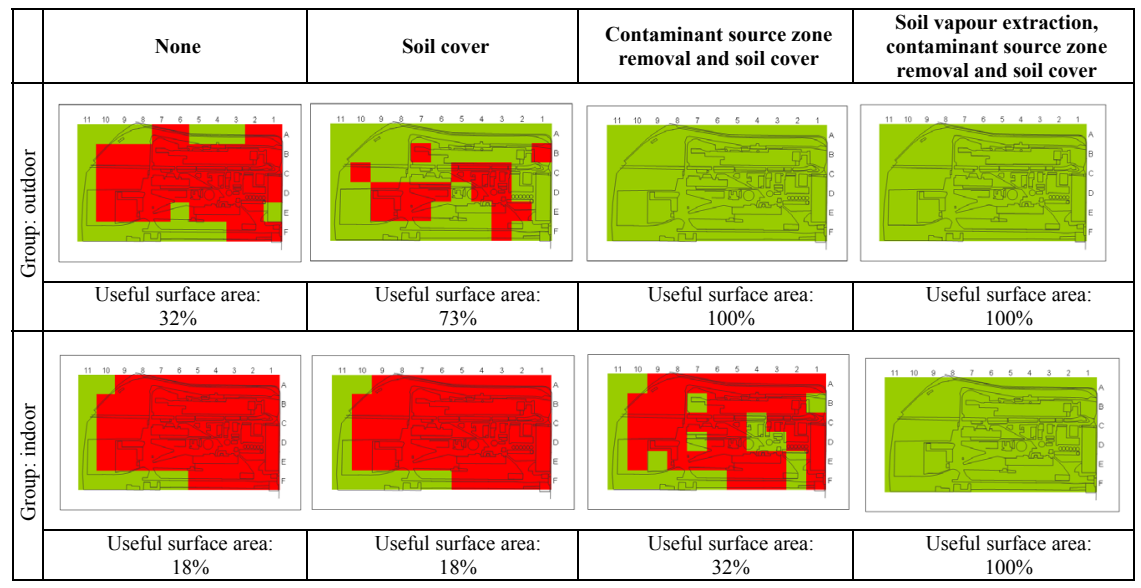

Figure 5: Useful area (light colour) for the 2 activity groups by implementation of different protection measures.

\subsection{Remediation plan}

In the next step the protection measures are transformed into a remedial plan. This implies that they are concretised in a remedial scope of work based on technical requirements, legislation, site conditions and site requirements for future use (e.g. heavy traffic, etc).

Table 2: $\quad$ Remedial options, unit costs and potential activities.

\begin{tabular}{|c|c|c|c|}
\hline Remedial option & $\begin{array}{c}\text { Estimated Cost } \\
\text { per } \mathbf{~ m}^{2}\end{array}$ & $\begin{array}{l}\text { Activity } \\
\text { group }\end{array}$ & Potential activities \\
\hline 1. Soil cover (gravel) & $€ 65$ & \multirow{2}{*}{ outdoor } & $\begin{array}{l}\text { (Car Terminal, outdoor storage, container } \\
\text { terminal, bulk transhipment) }\end{array}$ \\
\hline 2. Soil cover (asphalt/concrete)) & $€ 105$ & & $\begin{array}{l}\text { Car Terminal, outdoor storage, container } \\
\text { terminal, bulk transhipment }\end{array}$ \\
\hline 3. Source zone removal & $€ 80$ & -- & -- \\
\hline $\begin{array}{l}\text { 4. Source zone removal }+ \text { soil } \\
\text { cover (asphalt/concrete) }\end{array}$ & $€ 185$ & outdoor & $\begin{array}{l}\text { Car Terminal, outdoor storage, container } \\
\text { terminal, bulk transhipment } \\
\text { (warehouse) }\end{array}$ \\
\hline $\begin{array}{l}\text { 5. Soil vapour extraction, source } \\
\text { zone removal }+ \text { soil cover } \\
\text { (asphalt/concrete) }\end{array}$ & $€ 195$ & $\begin{array}{l}\text { outdoor } \\
\text { and indoor }\end{array}$ & $\begin{array}{l}\text { Car Terminal, outdoor storage, container } \\
\text { terminal, bulk transhipment, warehouse, } \\
\text { factory/logistics }\end{array}$ \\
\hline
\end{tabular}

For each remedial option a cost estimation is made. With these estimations remedial costs per $\mathrm{m}^{2}$ for the contaminated soil and groundwater area are calculated. Depending on the remedial option, these unit costs range from approximately $€ 65 / \mathrm{m}^{2}$ to $€ 195 / \mathrm{m}^{2}$. The potential activities in Table 2 , printed in italic and between brackets, represent activities that can only be applied on a limited area of the site. Those that are underlined can be applied to the full extent of the site. The cost estimation shows that remedial option 2 and 5 allow full use of the site for activity group indoor and outdoor respectively. Therefore these 2 remedial options are used to estimate the total cost to remediate the site, so that 
both indoor and outdoor industrial activities can take place. Figure 6 presents the estimated costs for both remedial options in relation to the percentage of area used by indoor and outdoor activities.

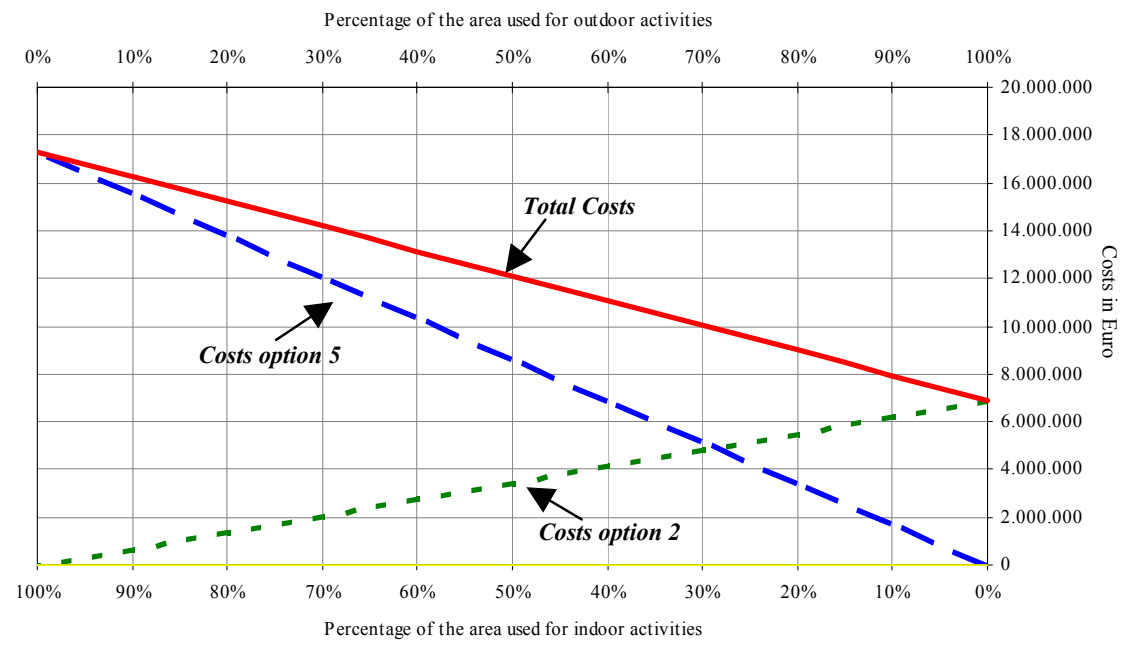

Figure 6: Cost estimation: option 2, option 5 and total cost.

From this estimation one can conclude that remedial costs allowing redevelopment for the selected industrial activities, can range from approximately $€ 7.000 .000$ to $€ 17.000 .000$, dependent on the selected industrial activities. The highest cost estimation is still more than $30 \%$ less than the initial cost estimation from the risk based remediation plan that was developed in 2003. This shows that the RRR-methodology can significantly reduce remedial costs an optimise land redevelopment.

\section{Future planning}

A next step is to add to the evaluation an estimation for local profits that can be made by redeveloping the site for the selected activities. This will allow for a further cost optimisation. Currently no concrete redevelopment scenario has been designed. The Flemish authorities are awaiting the finalisation of the master plan for the Zeebrugge Harbour before taking further actions. Meanwhile the conclusions of the RRR-methodology are being used to allow temporary use of the site as an outdoor storage facility, taking into account the soil cover protection measure.

Soresma is currently upgrading the RRR-methodology to be linked with a probability modelling tool (Cristal Ball ${ }^{\circledR}$ ) and a geostatistical data analyser $(G S l i b \AA)$ [9]. Both add-ons will allow to determine the sensitivity of the different parameters in the model, to see where additional data needs to be collected and determine the uncertainty of the different calculations and conclusions of the spatial data. 
112 Sustainable Development and Planning III

\section{References}

[1] Nuyens, D. \& Van Nieuwenhove, K., Soil survey Carcoke, SGS Ecocare Consultants, ref. 95.0623, 1995-1996;

[2] Vanhaecke, P. \& De Lembre, H., Descriptive soil survey Carcoke, Ecolas - RDC, ref. 9609/123, 1998;

[3] Maebe, P., Mergaert, K., De Lembre, H. \& Vandecapellen, A., Remediation project Carcoke, Ecolas, ref. 98/2636/HD, 1998-1999;

[4] Van Nieuwenhove, K. \& Coopman, A., Remediation project Carcoke Lisseweegsesteenweg 12 Zeebrugge, Soresma, ref. 12067809111, 2003;

[5] Van Gestel, G., Engels, R. \& Dries, V., Basis information for riskassessments, OVAM, 2004

[6] Standard Guide for Risk-Based Corrective Action Applied at Petroleum Release Sites, ASTM, E1739-95, 2002

[7] Standard Guide for Risk-Based Corrective Action, ASTM, E2081-00, 2004

[8] Schrooten, P., Peeters, S. \& Degreef, M., Beuselinck, L., Historical and industrial heritage evaluation Carcoke Zeebrugge, ERM - Signa, ref. PB7528, 2004;

[9] Goovaerts, P. Geostatistics for Natural Resources Evaluation, Oxford Univ. Press, New-York, 483 p. 1997. 